\title{
Ethnic and Regional Violence in Nigeria: Implications for National Security
}

\author{
David Adams $^{1} \&$ Ufiem Maurice Ogbonnaya ${ }^{2}$ \\ ${ }^{1}$ Department of Political Science, University of Uyo, Uyo, Nigeria \\ ${ }^{2}$ Research Division, National Institute for Legislative Studies, National Assembly, Abuja, Nigeria \\ Correspondence: David Adams, Department of Political Science, University of Uyo, Uyo, Nigeria. E-mail: \\ udoadamjp@gmail.com
}

Received: May 13, 2014 Accepted: May 27, 2014 Online Published: August 25, 2014

doi:10.5539/jpl.v7n3p20 URL: http://dx.doi.org/10.5539/jpl.v7n3p20

\begin{abstract}
With particular focus on Nigeria, this paper examined the security challenges posed to nation - states by "violent non-state actors" such as Boko Harram and Niger Delta Militia. It also studied the linkages between the process of globalization and the rise and expansion of these non-state actors. Findings indicated that core attributes and responsibilities of the state system such as territoriality, monopoly of means of violence and coercion, maintenance of law and order and the protection of lives and property have been challenged in the main by the preponderance of violent groups within the state. Thus, the paper recommended among other things, a thorough understanding of the operational methodologies of all ethnic and regional-based violent groups in Nigeria by national security operatives, a global agreement and cooperation to be reached among nations in various areas in order to bridge socio-economic inequalities which results in aggressive behaviours among the less privileged and reduce global insecurity. It also drew attention to the imperativeness of security sector reforms in Nigeria.
\end{abstract}

Keywords: Boko Haram, globalization, national security, Nigeria, Niger delta militancy

\section{Introduction}

\subsection{Background Information}

One fundamental responsibility of the state is the security of the life and property of its citizens. Others include the protection of its territoriality and sovereignty and the guarantee of its socio-economic and political stability. However, this protective function of the state has been threatened by the emergence of "violent non-state actors" who engage in violence and terrorism-related activities. This threat has been accentuated by the September 11, 2001 bombing of the World Trade Centre (WTC) in the United States by the Al-Qaeda terrorist network and similar attacks in Spain and Great Britain (Duru \& Ogbonnaya, 2010). In Nigeria, incidences of kidnapping, hostage taking and militancy in the Niger Delta region and the Boko Haram insurgency in the northern states are cases in point. In Somali, the operations of religious fundamentalists and ethnic militia groups aided by international terrorist groups have crippled governmental operations and state functions. In Mali, ethnic Tuareg fighters aided by foreign terrorist groups have occasioned a complex and overlapping political, security and humanitarian crisis in the state (CNN. 3 June 2012; Francis, 2013; International Crisis Group, 2013).

Consequently, the pursuit of the protection of national security, territorial authority and sovereignty of nation-states by state actors has been on the ascendancy, assuming a global dimension. The reason is that international and local terrorism have been recognized as potent threats to the security and sovereignty of nation-states and their citizens. The rise and expansion of violent non-state actors has been engendered by the process of globalization. With the aid of globalization, violent groups have become powerful national security challengers which the nation-states in most cases are not adequately prepared to encounter (Aydinli, 2006; William, 2008).

Using Nigeria as a focus, this paper examined the security challenges posed by the militancy in the Niger Delta region and the Boko Harram insurgency in the northern states to the Nigerian state. It also proffered policy recommendations that could contribute to the policy making process on national security related issues in Nigeria. 


\subsection{Statement of the Problem}

Since the mid-2000s, national security crisis in Nigeria has been escalated by the rise of ethnic Ijaw militant groups in the Niger Delta region and Boko Haram insurgency in the northern states. On the one hand, militancy in the Niger Delta is regarded as a response to poverty, environmental degradation and pollution within the region occasioned by oil exploration and the operations of oil multinationals and long years of government neglect and insensitivity to the plight of the people (Ogbonnaya, 2011). On the other hand, the emergence of Boko Haram has been viewed from two perspectives. While some have argued that it is occasioned by poverty and the struggle for the control of economic and political power among the political elite in the north, others have argued that it is a fallout of the on-going global attempt to radicalize Islam and instigate global jihadism with the ultimate aim of challenging the Westernization of the international system by the United States and its European allies (Eso, 2011; Awoyemi, 2012; Harrington, 2012; Walker, 2012).

Be that as it may, the issue is that militancy in the Niger Delta and Boko Haram in the north are constituting security challenges to the Nigerian state. In proving this, it becomes imperative to ask some questions;

1) How have the activities and operations of the Niger Delta militants and Boko Haram insurgents threatened the sovereignty and territoriality of the Nigerian state?

2) How has the emergence of these violent groups constituted threats to the security of lives and property of Nigerian citizens?

3) What impacts have the operations of these "violent non-state actors" had on economic growth in Nigeria?

4) To what extent has the emergence of militancy and Boko Haram been aided and sustained by the process of globalization?

\subsection{Objective of the Study}

The general objective of this paper is to examine the challenges posed to the Nigerian state by the emergence of militancy in the Niger Delta region and Boko Haram insurgency in the northern states. Specifically, the paper seeks to;

1) Assess the extent to which the operations of the violent non-state actors have constituted threats to the sovereignty and territoriality of the Nigerian state;

2) Examine the impact of the operations of these violent groups on the security of lives and property of Nigerian citizens;

3) Examine the impact, if any, of the operations of the groups on Nigeria's economy; and

4) Assess the relationship between globalization and the emergence and sustenance of regional violence and violent activities in Nigeria.

\section{Literature Review and Theoretical Direction}

\subsection{Literature Review}

The concepts of security and insecurity are typical social science concepts that appear principally in the literature of social psychology, sociology, political science and allied subjects. In the framework of political science, the concept of security according to Bar-Tal and Jacobson (1998:2) denotes a situation which provides national and international conditions favorable to the protection of a nation, state, and its citizens against existing and potential threats. The socio-psychological conceptual framework of security on the other hand, acknowledges the military, political, economic and cultural conditions, which play an important role in creating situations of security. Specifically, however, the situation of security assures a survival of a state, its territorial integrity, repulsion of a military attack, defense and protection of citizens' life and property, protection of economic welfare and social stability (Haftendorn, 1991).

Analysts have examined the problem of insecurity generally from various perspectives. Cameron and McCormic (1954) have pointed out nine different sources of insecurity, namely; insecurity as emotional response to sudden external threats from within; insecurity from a relatively constant threatening external situation; insecurity due to threat from within; and insecurity as a function of beliefs, especially religious; etc. These categories of insecurity are caused by "frustration and neurosis" (Cameron \& McCormic (1954:559). This classification notwithstanding, Cameron and McCormic's work contains little of what can be regarded as empirical research on insecurity. This is because the work is filled with speculations without empirical evidences. In addition, issues raised are not exhaustively discussed. 
Bar-Tal and Jacobson (1998) have also examined issues of security and insecurity. Using the security challenges in Israel as a case study, they specifically concerned themselves with approaches and methods of dealing with security situations. Thus, two main approaches to security studies were indentified, namely, political and socio-psychological approaches. According to the political approach, security is an essential precondition of an ordered existence for an individual and societal system. Here, individuals and collectives must have a secured environment, which allows them to pursue their goals without being subjected to threats. The argument of this approach is that, it is the role of the state to provide security to its citizens, both on internal and external levels. On the domestic level, the state has to create economic, societal, cultural, environmental, and educational conditions, which assure life to its citizens. On the international level, the state has to defend the citizens against possible harm from external forces (Buzan, 1991). Thus, this approach is concerned with military alliances, and foreign policy. Comprehensive as this approach may be, it neglects the economic, societal, cultural and psychological issues, which are imperative to the study of security. The socio-psychological approach on the other hand, argues that people as individuals and/or as group members (e.g., members of economic groups, nations) experience security, or insecurity, with regard to own personal life and/or with regard to their collective entity and its systems. Security thus, is a psychological experience. Generally, however, the paper did not explain, using both approaches to the study of security, what primarily causes insecurity in any given society.

In another study, Ellen, Salemink and Eriksen (2010), examined security and insecurity from an anthropological perspective. Here, attempts were made to conceptualize insecurity from the perspective of social and human security. However, the major flaw of the paper is that it did not contextualize insecurity. In other words, the study did not locate insecurity within a given geographical environment or location.

With particular reference to Nigeria, Ezeribe (2009) has catalogued a history of conflicts and insecurity in Nigeria since independence in 1960. Here, the conflicts, which result in insecurity are traced to the colonialists creating antagonistic ruling class along ethnic and religious lines. Thus, the northern part of Nigeria has had a long history of security challenges, communal and ethno-religious crises. For example, in Plateau State, there have been many outbreaks of bloody violence between different communities since the return to democracy in 1999. There have also been riots in urban centers of Kaduna and Kano, and for several decades there has been simmering conflict in the Tafewa Balewa district of Bauchi (Walker, 2012). According to Walker (2012) and Azizi (2012), when viewed from outside, it does seem that these conflicts boil down to religious differences, tensions between blocs of Muslim and Christian inhabitants. But on a closer consideration, one finds that politics - more precisely, control of government patronage - is the primary cause of many of these conflicts. However, the Boko Haram insurgency which surfaced in 2009 with bombing attacks and killings which as at last count, have left over 16,000 Policemen, soldiers and civilians including politicians dead (UNCIRF, 2012) remains one of the recent trends in regionally-based related-violence dimensions to security challenges facing Nigeria.

Book Haram, otherwise known as Jamaatul Alissuma lid da a wa wal Jihad, started its operation in Bauchi State on July 26, 2009 and has since spread to other States in the northern parts of Nigeria. Since then, the group has existed with known preferences in religious belief ad social practices. But as Eso (2011) has observed, "the root causes of resort to violence and criminality in order to influence public policy is rather deep-seated and beyond the sectarian". This is because the attacks of the group have been targeted or directed at the State, its institutions, and the civilian populations. Several police stations including the Force Headquarters, Abuja; army barracks, schools, government establishments and places of worship have been attacked in several states of the Federation. But the attack on the UN office in Abuja in 2011 was, according to Eso (2011), "a game-changer with new dynamics, far reaching and imponderable reverberations that dramatically altered the scope, intensity, and focus of Boko Haram's Voilence and mission, as well as any consideration of sect". Thus, some analysts have argued that the Boko Haram induced security crisis in the north is more religious than political. Those who argue along this line submit that beginning from 1987 to the controversial introduction of Sharia penal system by some States in the north in 2000, some political leaders have laid the foundation for extremist sects to emerge through religious manipulation which coupled with widespread illiteracy, poverty and a weak leadership, has since allowed a violent group like Boko Haram to emerge (Harrington, 2012; Punch Editorial, February 19, 2012). Others have argued that the current insecurity is worsened or aided by the high level of poverty in that region in particular and Nigeria in general (Awonyemi, 2012). According to Awoyemi (2012), “...the Boko Haram phenomenon has a deep economic root more than any other perspectives from which the investigating intelligence can suggest". These realities are much more obvious in rural areas. A factual indicator is the result of the Harmonized Nigeria Living Standard Survey published by the National Bureau of Statistics in 2012, which showed that the North scored badly and accounted for the large proportion of Nigerians living in poverty. Another analyst who has urged along this perspective is Jonnie Carson, US Assistant Secretary of State for 
African Affairs. According to him, "religion is not driving extremist violence either in Jos or northern Nigeria" (Harrington, 2012). Others have contended that violence in the north is orchestrated by the betrayal of peoples trust in government. According to Mr. Terence McCulley (the US Ambassador to Nigeria), the betrayal of people by the governments and the low level of government presence provided criminals a platform to launch insurrection being witnessed across northern Nigeria (Benjamin, Ogunmola, Joseph \& Ibrahim, 2012). Be that as it may, the major focus of this paper is to examine the impact of insecurity on the socio-economic development of northern states.

Other security analysts have contended that the current security challenges confronting the Nigerian state is capable of making the country porous for internal and external subversion and insurrection. Thus, they have called for more stringent security measures and policies rather than being saddled with peace-keeping operations in other countries while lacking the ability to deal with internal security crisis, conflicts and tensions. Finally, these analysts have submitted that current national defense budget and policy should be properly channeled towards economic, social and political development (Agbambu, 2011; Azazi, 2012).

\subsection{Theoretical Framework}

This work utilized the Instrumental Theory of or violence. This is because; apart from its ability to explain the organizational structure of violent groups such as Boko Haram, the theory adequately captures and explains the whole gamut of explanatory variables and the dynamics that inform the reasons why violent groups operate and their methodology of operation. The Instrumental Theory of violence is associated with scholars such as Edward Mickolus (1976), Richard Betts (1982), and Martha Crenshaw (1985). It is premised on the assertion that the act of terrorism is a deliberate choice by a political actor and that the organization, as a unit, acts to achieve collective values, which involve radical changes in political and social conditions (Crenshaw, 1985:13). Here, terrorism is interpreted as a response to external stimuli, particularly government actions. The major thrust or basic assumption of this theory is that violence is intentional. Terrorism is a means to a political end. Schelling (1966) suggests that terrorism is one form of violent coercion, a bargaining process based on the power to hurt and intimidate as a substitute for the use of overt military force. As such it is similar to other strategies based on the power to hurt rather than conventional military strength. Within this context, terrorism is meant to produce a change in the government's political position, not the destruction of military potential. The theory also submits that non-state organizations using terrorism is assumed to act on the basis of calculation of the benefit or value to be gained from an action, the cost of the attempt and of its failure, the consequences of inaction, or the probability of success. According to Betts (1982), violent actions may occur for several reasons; the value sought for is overwhelmingly important; costs of trying are low; the status quo is intolerable; or the probability of succeeding (even at high cost) is high. Thus, violent groups may act out of anticipation of reward or out of desperation, in response to opportunity or to threat. This strategic perspective, according to Betts (1982), is a conceptual foundation for the analysis of surprise attacks. Thus, he concludes that violence is par excellence a strategy of surprise, necessary for small groups who must thereby compensate for weakness in numbers and destructive capability.

Applied within the context of Nigeria' security challenges, the Boko Haram Islamic sect believes that politics in northern Nigeria has been seized by a group of corrupt, false Muslims and thus seeks to wage a war against them, and the Federal Republic of Nigeria generally, to create a "pure" Islamic state ruled by Sharia law. Since August 2011 Boko Haram has planted bombs almost weekly in public places or in churches in Nigeria's north east region in particular and the north in general. The group has also broadened its targets to include setting fire to schools. In March 2012, some twelve public schools in Maiduguri were burned down during the night, and as many as 10,000 pupils were forced out of education (Walker, 2012).

Though the theory explicitly explained the organizational structure of violent groups like Boko Harram, the variables and dynamics that inform the reasons why they operate and their method of operations, using the same theoretical framework, it becomes difficult to establish any link between the operations of Boko Harram and the socio-economic activities of northern Nigeria.

\section{Globalization as Force Multiplier of Terrorism: Evidence from Nigeria}

Multiplication of actors in international relations is one of the major trends in the development of contemporary international politics. This came to a climax in the twenty - first century. These actors are classified into state and non-state actors. Among the non-state actors in international politics are international terrorist groups otherwise called "violent non-state actors" (Williams, 2008). All non-state actors in international politics whether violent or not, have some features and characteristics in common that enable them to initiate, participate and, often, influence the outcome of international relations. One of such characteristics is that they espouse and 
promote ideas, beliefs and courses of action whose impacts cut across several independent and sovereign states. Thus, whether it is the international working class ideology of Marx, Charismatic Catholicism, or ethnic minorities such as the Ogonis of Nigeria and native Indians of the Amazon forest or the Boko Haram insurgent group in the northern part of Nigeria or the Al-Qaeda terrorist networks, these movements have become recognized and are increasingly gaining global relevance and significance.

A number of scholars (Williams, 2008; Negroponte, 2006; Ampatuam, 2003) have successfully established a nexus between the emergence and prevalence of modern international terrorism and globalization especially since the twenty - first century. According to Williams (2008), although terrorism has a long historical background, an important factor in the understanding of the rise of Violent Non-State Actors (VNSAs), over the last few decades is globalization. Williams submits that not only has globalization challenged individual state's capacity to manage economic affairs, it has provided facilitators and force multipliers for VNSAs. According to him, global flow of arms, for example is no longer under the exclusive control of nation - states. Illicit arm dealers have become transnational players and have contributed to a diffusion of military power that has provided VNSAs with weapon capabilities that allow them to challenge government forces. In a similar vein, globalization has allowed Violent Non-State Actors to develop transnational social capital and to create alliance and generate support outside their immediate area of operations. Globalization, along with the rise of illicit global economy has also provided funding opportunities for Violent Non-State Actors and other terrorist groups generally.

In 2006, John Negroponte, then Director of U.S. National Intelligence wrote thus;

The 21 st century is less dangerous than the 20th century in certain respects, but more dangerous in others. Globalization, particularly of technologies that can be used to produce weapons of mass destruction (WMD), has led to the spread of jihadist movements, and of course, the horrific events of September 11, 2001 (Negroponte, 2006:1, 2).

In addition, Ampatuam (2003:1) submits that while globalization has brought unprecedented development and progress to people, it has also unleashed negative aspects such as "facilitating international terrorism and other forms of transnational crimes." According to him, transnational terrorism is a global phenomenon which is seen as one of the most destructive. The September 11, 2001 attacks on the United States of America illustrate the lethality of this threat.

In Nigeria, globalization has facilitated the prevalence of terrorism and violent groups such as the Boko Haram and the many militant groups in the Niger Delta region. This is evident in the method and means of their funding, supply of logistics and weapon system, training, coordination and flow of information of the groups. For instance, the security operatives in Nigeria have established a link between the Boko Haram and the many terrorist groups that are directly or otherwise engaging in the current political and security crises in the West African state of Mali, namely the Islamist Ansar Dine ("Defenders of the Faith"), Al Qaeda in the Islamic Maghreb (AQIM) and Jama'a al Tawhid wa al Jihad fi Gharb Afriqiya (The Movement for Unity and Jihad in West Africa, MUJWA), from where its operations and activities are coordinated. The Boko Haram group also has ties with Somalia's al-Shabaab while its membership has spread to other West African countries such as Cameroun, Benin Republic, Niger, Mauritania, and Chad which also provides sanctuary for the group's members (Okpaga, Chijioke \& Eme, 2012).

Secondly, because violent groups receive both funding and logistics from international sources and because globalization has enabled illicit arms dealing and free movement of goods and services and illicit global economy such as oil bunkering to flourish, many of these groups have sprung up. This is mostly the case with the militant groups in the Niger Delta region where groups such as the Movement for the Emancipation of the Niger Delta (MEND) led by Henry Okah, the Niger Delta People's Volunteer Force (NDPVF) led by Alhaji Asari Dokubo, the Niger Delta Vigilante force (NDVF) led by Ateke Tom, the Bush Boys, the Martyrs Brigade among others operate (Cesarz, Morrison \& Cooke, 2003).

Apart from their international connections, sources of funding and logistics, the organizational structures, coordination of the activities and operations of the terrorist groups have been enhanced by the use of global system of communication such the cell phones, internet, websites, media releases. These are all processes of globalization (Afoaku, 2011). Thus, sources of funding, training and supply of weapons of terrorist groups have been aided by a global system that encourages free flow of liquid cash, information and easy movements of human beings. A recent United States report indicated that Boko Haram receives funding and training from international terrorist groups such as al-Qaeda in the Middle East, al-Qaeda in the Islamic Maghreb (AQIM) and radical Islamic group, Al-Muntada Trust Fund, based in the United Kingdom (Nigerian Tribune, February 12, 
2012). With regard to the Niger Delta Militants, Ebienfa and Nwaodike (2010) have argued that globalization has swell up the capacity of the Militant groups in terms of logistics, funding and training opportunities. This according to them is evident by the fact that advances in communication and information technologies now have serious implications and outcomes on the Niger Delta crisis. As for the sources of the Militants' weapons, analysts have submitted that illicit arm dealers created by a global system of interconnectedness supply weapons from various locations. In 2006, the River State Police Command arrested one Chris Ndudi Njoku, a 45 year-old Nigerian who along with his foreign counterparts, specializes in the importation of prohibited firearms into Niger Delta region. This coincided with the arrest in South Africa of a leader of the Movement for the Emancipation of the Niger Delta (MEND), the most potent and leading Militant group in the region, for acquisition of illegal arms and weapons (CEHRD, 2006). Consequently analysts have argued that in identity terms, without the power of the internet and social media, al-Qaeda's efforts to project and position radical Islam as an alternative response to 'Western modernity' could not have been nearly as global in scope (Trzeciak-Duval \& Van Veen, 2012). The same applies to the operations of the militants and Boko Haram in the Niger Delta region and northern part of Nigeria respectively.

The effort of the Nigerian state and its security operatives in combating ethnic and regional violence have on the one hand been sustained by the process of globalization and on the other retarded by the same global process. For instance, the State Security Service agents have depended on modern technologies of global communication in tracking the movements and trailing the operations of militant and violent groups within and outside the state. The arrest of key members and leaders of these been facilitated by multiplicity of factors such as the use of modern communication gadgets and cooperation with international security agencies, multilateral military organizations and national governments. The recent security agreement between the Nigerian government and the Cameroonian, Chadian and Nigerien authorities to closely monitor their borders, as well as the bilateral agreements between Nigeria and some Western countries and the United States to assist in combating the activities of these groups in Nigeria are evident (Okpaga, et al, 2012:86). However, the security operatives in Nigeria have not been successful in blocking the international sources of funding, provision of logistics and supply of weapons for violent groups despite attempts to do so. Consequently, it can be reasonably asserted that globalization has both strengthened and weakened the role of the Nigerian state in contending with violent groups in the country. Thus, like most states, intensifying global transformations in Nigeria is meeting with adventurous and empowered individuals and groups and has begun to allow the creation of autonomous and independent non-state actors as security challengers. This has ultimately forced nation states into a struggle against newly emerging actors whom they are poorly prepared to encounter. As Aydinli (2006) has argued, this rising security challenges posed by these violent non-state actors are exceeding the capabilities of states and those who act on their behalf to contend with.

\section{National Security Challenges in Nigeria}

From the foregoing, it is taken for granted that international terrorism has in the recent past been propelled by the current form and dimension of globalization. However, a more worrisome dimension is not what propels international terrorism, but that international terrorist groups not only represent a common challenge to national and international security, they have also, in the twenty - first century, emerged so powerful that the state monopoly of the use of force is increasingly being reduced to a convenient fiction such that relatively few of the sovereign states represented in the United Nations can truly claim monopoly of force within their territorial borders.

In Nigeria, the preponderance of militia and violent groups with international linkages has constituted potent threats to national security and economy, unity, sovereignty and territorial integrity of the state and its citizens. For instance, the activities of the groups have resulted in the loss of lives and property. A recent statistics released by Niger Delta Development Monitoring and Corporate Watch (NIDDEMCOW), a non-governmental organization, shows that between 1999 and 2007, a total of 308 hostage taking incidents occurred in the region. A breakdown of this record shows that Bayelsa State was on the lead with 131 incidents. Rivers State had 113; Delta State 45, while Akwa Ibom had the least record of 15. The record further shows that in 2003, 18 oil workers were taken hostage in Bayelsa, in 2004, 5 hostages, 39 in 2006 while between January and June, 2007 69 people were taken hostage, out of which 50 were soldiers. Within the period under review, Rivers State recorded 2 incidents in 1999, one in 2005, 55 in 2006 and 60 as at June, 2007, with 26 soldiers, 1 woman and a three year-old child involved. Unfortunately, the situation has since then deteriorated and the spate of militancy, hostage taking and kidnapping incidents have increased in scope and tempo covering virtually all the oil producing states of Nigeria.

In addition, militant groups have carried out deadly and paralyzing attacks on oil and gas facilities with their 
weapons. For instance, on March 16, 2003, Shell Petroleum Development Corporation (SPDC), Nigeria's biggest oil producing company, evacuated non-essential staff from its facilities in Warri, Delta State, and shut down oil production, following a mouth of mounting unrest by ethnic Ijaw militant groups that culminated in an attack on the Nigerian Navy on the Escravos River that left seven people dead, several soldiers wounded, and significantly disrupted riverine travel. Subsequent attacks by militants killed one Chevron contract worker and five TotalFinalElf (IFE) personnel, while gunfire badly damaged a shell helicopter seeking to evacuate employees (Cesarz, et al, 2003:1). On July 12, 2006, the Movement for the Emancipation of the Niger Delta (MEND) combatants killed four naval personnel and injured three soldiers who were escorting a Chevron oil tanker along Chomoni creeks in the Warri South West Local Government Area of Delta State. On the eve of the Governorship and House of Assembly elections on April 14, 2007, armed militants attacked the Mini-Okoro, Elelenwo Police Stations, killing many police officers during the attack. On Tuesday, January 1, 2008, the Niger Delta Vigilante Force (NDVF) attacked two Police Stations and a five star hotel in Port Harcourt. The list of attacks is long and seemingly endless. The latest being the bomb blast at Eagles Square in Abuja on October 1, 2010 by Movement for the Emancipation of the Niger Delta, MEND. Though some analysts have contended that the issue at stake in the Niger Delta is the demand by ethnic nationalities for greater autonomy and control of the oil resources, equitable distribution of the benefits of oil mineral exploitation, environmental justice and the development of the region, yet the activities of the militants constitute acts of international terrorism having taken up arms against the Nigerian state, kidnapped expatriate oil workers and blown up oil installations belonging to oil Multinational Corporations.

On the other hand, the Boko Haram group, otherwise called Jamaatul Alissunna lid da a wa wal Jihad, surfaced with bombing attacks and killings which as at the last count, have left over 10,000 Policemen, Soldiers and civilians including women and children dead (USCIRF, March 20, 2012; IOL News, 2012) (see Table 1).

Table 1. Timeline of terrorism-related violence in some parts of northern Nigeria (July 2009 - July 2012)

\begin{tabular}{|c|c|c|}
\hline Date & Incidence \& State of Occurrence & Responsibilit \\
\hline July 27, 2009 & $\begin{array}{l}\text { Attack on Potiskum Divisional Police Headquarters, Yobe State leading } \\
\text { to the death of } 3 \text { Police Officers and } 1 \text { Fire Service Officer }\end{array}$ & Boko Haram \\
\hline March 13, 2010 & $\begin{array}{l}300 \text { persons killed in an operation in the Northern part of Jos, Plateau } \\
\text { State }\end{array}$ & Boko Haram \\
\hline September 7, 2010 & $\begin{array}{l}\text { Bauchi Central Prison was set ablaze and leading to the setting free of } \\
\text { Sect member }\end{array}$ & Boko Haram \\
\hline October 1,2010 & Eagle Square Bomb Attacks, Abuja & MEND. \\
\hline December 24, 2010 & 8 people killed in a bomb attack in Barkin Ladi, Jos, Plateau State & Boko Haram \\
\hline December 31, 2010 & 10 persons killed in Abuja Bomb Attacks at Mogadishu Mammy Market & Boko Haram \\
\hline January 21,2011 & 8 persons killed by gunmen in Maidugri, Borno State & Boko Haram \\
\hline March 2, 2011 & $\begin{array}{l}2 \text { Police Officers attached to the residence of the Divisional Police } \\
\text { Officer, Mustpha Sandamu at Rigasa area of Kaduna State killed }\end{array}$ & Boko Haram \\
\hline March 30, 2011 & Bom explosion in Damaturu, Yobe State & Boko Haram \\
\hline April 8, 2011 & $\begin{array}{l}8 \text { serving Corps Members killed in a bomb explosion at INEC Office, } \\
\text { Suleja, Niger State }\end{array}$ & Boko Haram \\
\hline April 22, 2011 & Yola Jail Break (Boko Haram frees 14 prison inmates) & Boko Haram \\
\hline April 29, 2011 & Bomb attack at the Army Barracks in Bauchi State & Boko Haram \\
\hline May 29, 2011 & $\begin{array}{l}\text { 1. Bomb blasts in Zuba International Market, Abuja. } \\
\text { 2. Bomb blasts in a market near } 33 \text { Artillery Brigade, Bauchi. } \\
\text { 3. Bomb blasts in Zaria, Kaduna State. }\end{array}$ & Boko Haram \\
\hline June 7, 2011 & 5 persons killed in a series of bomb blasts in Maiduguri, Borno State & Boko Haram \\
\hline June 16,2011 & Bombing of Police Force Headquarters, Abuja. & Boko Haram \\
\hline
\end{tabular}


June 16, 2011

June 20, 2011

June 26, 2011

June 10, 2011

July 10, 2011

July 11, 2011

July 15, 2011

July 23, 2011

August 12, 2011

August 26, 2011

September 122011

September 172011

October 3, 2011

November 4, 2011

November 272011

December 18, 2011

December 22, 2011

December 24, 2011

December 25, 2011

December 30, 2011

January 5, 2012

January 6, 2012

January 20, 2012

January 22, 2012

January 26, 2012

January 28, 2012

January 30, 2012

February 4, 2012

February 5, 2012

February 7, 2012
4 children killed in a bomb blast at Damboa town, Maiduguri, Borno State

7 Police Officers killed in a gun attack at Kankara Police State, Katsina State and 2 security men guarding a property opposite the Police Station

Bomb attacks in a beer garden in Maiduguri.

Boko Haram

Over 31 persons killed in a clash between sect members and security operatives in Maiduguri, Borno State;

Bomb attacks at All Christian Fellowship Church in Suleja, Niger State

Explosion at a recreation centre along Fokados Street, Kaduna, Kaduna State

5 persons killed in an explosion in Maiduguri, Borno State

3 Military Officers injured in a bomb blast near the Palace of the Shehu of Borno, Abubakar Garbai Elkanem

Prominent Muslim Cleric, Liman Bana is shot dead in Maiduguri.

United Nations House bombing attacks in Abuja

7 persons including 4 Police Officers killed in a bomb explosion at a Police Station in Misau, Bauchi State

Brother-in-law to Mohammed Yusuf, the slain leader of Boko Haram, Babakura Fugu, shot dead in front of his house by 2 gun men two days after after he was visited by former President Obasanjo

3 persons killed in an attack in Baga Market in Maiduguri, Borno State 150 persons killed in a bomb attack in Damaturu, Yobe State

7 persons killed in attacks in Geidam, Yobe State

3 members of the Sect killed when their bomb detonated in Shuwari, Maiduguri, Borno State

4 persons severely injured by explosions and gun shots in Borno State

80 persons killed in multiple bomb attacks in Jos, Plateau State

50 killed in bomb attacks at St. Theresa's Catholic Church, Madalla, Niger State.

7 people killed in Maidugri, Borno State

Bomb attacks in a Church in Gombi, Adamawa State

Gunmen attacked a Town Hall Meeting by Igbo Traders in Mubi, Adamawa State.

250 people killed multiple bombing of Churches and businesses in Kano

2 Churches bombed, 2 military offices, a DPO and 8 others killed by gunmen at the Headquarters of Tafawa Balewa LGA, Bauchi State

Bomb explosion in Sabon Gari, Kano State

Boko Haram

1 killed in Ngala, Borno State

6 people killed in Maidugri including 2 Air Force officers

2 people killed in Damboa, Borno State

SSS agent killed in Yobe State

Attack on Kaduna Markets and Military Barracks which resulted in the death of 5 people
Boko Haram

Boko Haram

Boko Haram

Boko Haram

Boko Haram

Boko Haram

Boko Haram

Boko Haram

Boko Haram

Boko Haram

Boko Haram

Boko Haram

Boko Hara

Boko Haram

Boko Haram

Boko Haram

Boko Haram

Boko Haram

Boko Hara

Boko Haram

Boko Haram

Boko Haram

Boko Haram

Boko Haram

Boko Haram

Boko Haram 
January 7, $2012 \quad$ Attack in Kano State that led to the death of 10 persons

February 8, 2012

February 10, 2012

Nigeria Army Headquarters suicide bomb attack, Kaduna State.

JTF-Boko Haram shoot-out in Maidugri, Borno State in which 4 persons died

February 10, 2012 Attack on Police State and Shari Quarters in Kano State

February 15, 2012 2 Police Officers killed in Minna, Niger State

February 16, 2012.

February 17, 2012

February 17, 2012

April 8, 2012

April 26, 2012

May 2, 2012

June 3, 2012

June 17, 2012

July 7, 2012

July 8, 2012
119 inmates

2 people killed in Geldam, Yobe State

5 people killed in Maidugri metropolis, Borno State

Violent group bombed a Church in Kaduna on Easter

Coordinated bomb attacks in ThisDay and Daily Sun Newspapers offices

in Abuja and Kano

Gunmen attacked Potiskum cattle market in Yobe States with explosives

Church bombing in Bauchi State.

Coordinated bomb attacks in 3 different churches in Zaria, Kaduna and Yobe State.

Barkin Ladi and Riyom Villages, Jos attack

Matse Village, Jos Massacre in Plateau State that resulted in the death of

Senator Gyang Dantong, Plateau State House of Assembly Majority

Leader and 50 others.
Boko Haram

Boko Haram.

Boko Haram

Boko Haram

Boko Haram

Boko Haram

Boko Haram

Boko Haram

Boko Haram

Boko Haram

Armed Robbery

Boko Haram

Boko Haram

Fulani herdsmen

Gunmen

suspected to be

Fulani herdsmen

Source: Author's compilation from various sources

The operations of the group started in Bauchi State on July 26, 2009 and have since spread to other parts of Nigeria especially the northern states. The group has since existed with known preferences in religious belief and social practices. But as Eso (2011) has observed, "the root causes of resort to violence and criminality in order to influence public policy is rather deep-seated and beyond the sectarian". This is because the attacks of the group have been targeted or directed at the State, its institutions, and the civilian populations. Several police stations including the Force Headquarters, Abuja; army barracks, schools, government establishments and places of worship have been attacked in several states of the Federation. But the attack on the UN House in Abuja in 2011 was, according to Eso (2011), "a game changer replete with new dynamics, far reaching and imponderable reverberations that dramatically altered the scope, intensity, and focus of Boko Haram's violence and mission, as well as any consideration of sect". Apart from the threat to live, national security, unity, sovereignty and territoriality, the operations of these violent groups have also impacted negatively on the Nigerian economy. For instance, in 2008 alone, it is estimated that Nigeria lost over 3 trillion Naira as a result of militancy in the Niger Delta while Boko Haram has caused extensive damage to property and reduced government revenue with a negative impact on the socio-economic development of the northern region in general and North-East states in particular (see Table 2).

Table 2. Internally generated revenue summary of north-east states (2010-2013)

\begin{tabular}{llccc}
\hline S/N & \multicolumn{1}{c}{ State } & $\mathbf{2 0 1 0}$ & $\mathbf{2 0 1 1}$ & $\mathbf{2 0 1 2}$ \\
\hline 1 & Adamawa & $4,208,037,777.45$ & $4,117,975,681.95$ & $4,615,407,803.00$ \\
2. & Borno & $2,108,612,985.25$ & $2,282,102,699.76$ & $2,444,613,205.37$ \\
3. & Gombe & $2,954,868,598.34$ & $3,153,362,788.35$ & $3,717,188,863.22$ \\
4. & Taraba & $1,284,745,422.40$ & $2,869,031,498.92$ & $3,418,289,991.33$ \\
5. & Yobe & $5,960,502,339.45$ & $2,385,653,776.94$ & $1,785,221,060.95$ \\
\hline
\end{tabular}

Source: National Bureau of Statistics (2013) 


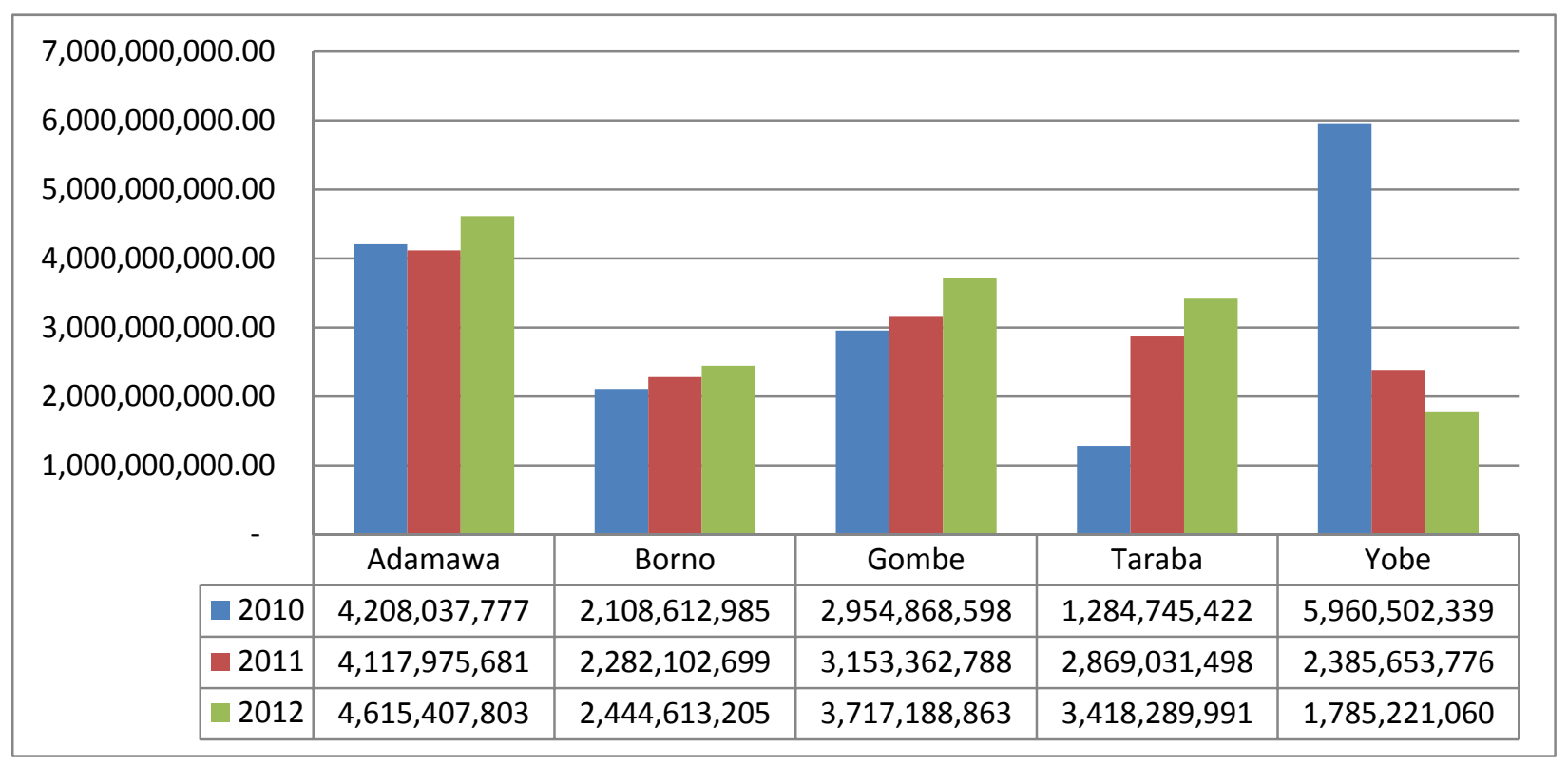

Figure 1. Internally generated revenue summary of north-east states (2010-2012)

Source: National Bureau of Statistics (2013)

The performance in government revenues in the states listed above has been staggering especially in Yobe and Borno States. This is attributed to the activities of violent groups like Boko Haram in that region. Compare this to the steady rise on government revenues in a region like the South-West where the activities of violent groups have been minimal (see Table 3)

Table 3. Internally generated revenue summary of south-west states (2010-2013)

\begin{tabular}{lllll}
\hline S/N & State & $\mathbf{2 0 1 0}$ & $\mathbf{2 0 1 1}$ & $\mathbf{2 0 1 2}$ \\
\hline 1 & Ekiti & $1,554,020,325.64$ & $2,489,797,191.33$ & $3,787,607,515.35$ \\
2. & Lagos & $185,892,565,812.12$ & $202,761,061,678.04$ & $219,202,426,843.89$ \\
3. & Ogun & $7,917,662,341.92$ & $10,838,698,403.20$ & $12,438,765,025.22$ \\
4. & Ondo & $6,480,372,918.69$ & $8,015,725,375.26$ & $10,153,042,597.01$ \\
5. & Osun & $3,376,735,645.43$ & $7,398,572,036.48$ & $5,020,250,633.94$ \\
6. & Oyo & $10,488,362,233.80$ & NA & $14,598,808,723.10$ \\
\hline
\end{tabular}

Source: National Bureau of Statistics (2013)

From the foregoing, the challenges posed by the emergence of violent groups in Nigeria are enormous. Examples from the Niger Delta militancy and the Boko Haram insurgency in Nigeria indicate that what the groups represent in terms of the global potential and feasibility for non-state actors as security challengers with destructive capabilities rivaling those of the state is alarming. This is because their modus operandi has defiled national security mechanism and the strategic dexterity with which they operate coupled with the sophisticated nature of their weapons have raised such questions as to the source of their military training and experience, weapon system and general logistics making some analysts to have them linked to other international terrorist groups like Al-Qaeda.

\section{The Imperative of Security Sector Reform in Nigeria}

From the foregoing analysis, the security crisis occasioned by terrorism in Nigeria not only challenges the adequacy and viability of Nigeria's security sector and its institutions in handling the crisis; it also points to the imperative of security sector reforms in Nigeria. There have however, been various attempts at security sector reforms in Nigeria since independence. At independence in 1960, government's primary mission was to 
safeguard the fledgling nation against external and internal attacks, leading to the Anglo-Nigeria Defence Agreement. However, popular protests by the Nigerian students against the agreement led to its abrogation in 1962 by the Nigerian government (Fayemi \& Olonisakin, 2008).

Following Nigeria's return to democratic governance in 1999, the Olusegun Obasanjo-led regime instituted some reforms in the core security sector. Basically, the reforms aimed at;

1) De-politicization and subordination of the military to civil authority;

2) Constitutionalizing and redefining the role and mission of the military;

3) Reorientation and re-professionalization of the core security sector; and

4) Demilitarization of public order and increasing relevance of civil Policing (Abiodun, 2000). This is presented in a tabular form below;

Table 4. Tabular presentation of security sector reforms in Nigeria

\begin{tabular}{|c|c|c|c|c|}
\hline Year & Reform & Regime & Output & Outcome \\
\hline $1960-1966$ & $\begin{array}{l}\text { The Anglo-Nigeria } \\
\text { Defence } \\
\text { Agreement }\end{array}$ & $\begin{array}{l}\text { Sir Abubakar } \\
\text { Balewa Regime }\end{array}$ & $\begin{array}{l}\text { Government signed a pact with } \\
\text { the British government for the } \\
\text { training of Nigeria's security } \\
\text { forces. }\end{array}$ & $\begin{array}{l}\text { Safeguard the newly } \\
\text { independent Nigeria } \\
\text { against external and } \\
\text { internal attacks }\end{array}$ \\
\hline \multirow[t]{2}{*}{1999} & \multirow[t]{2}{*}{$\begin{array}{l}\text { De-politicization } \\
\text { of the Armed } \\
\text { Forces }\end{array}$} & \multirow[t]{2}{*}{$\begin{array}{l}\text { Olusegun } \\
\text { Obasanjo Regime }\end{array}$} & $\begin{array}{l}\text { (1). The retirement of } 93 \text { armed } \\
\text { officials ( } 53 \text { from the army, } 20 \\
\text { from the Navy, } 16 \text { from the } \\
\text { air-force and } 4 \text { from the police) } \\
\text { who had held political offices. }\end{array}$ & \multirow[t]{2}{*}{$\begin{array}{l}\text { Subordination of the } \\
\text { Armed Forces to } \\
\text { Civil Authority }\end{array}$} \\
\hline & & & $\begin{array}{l}\text { (2).The government's } \\
\text { announcement of an } \\
\text { anti-corruption crusade that saw } \\
\text { the immediate termination of } \\
\text { several contracts awarded by the } \\
\text { erstwhile military administration } \\
\text { as well as the setting up of a } \\
\text { judicial commission to } \\
\text { investigate human rights } \\
\text { violations under the military. }\end{array}$ & \\
\hline 1999 & $\begin{array}{l}\text { Re-orientation \& } \\
\text { Re-professionaliza } \\
\text { tion Policy }\end{array}$ & $\begin{array}{l}\text { Olusegun } \\
\text { Obasanjo Regime }\end{array}$ & $\begin{array}{l}\text { (1).Re-equipping the services and } \\
\text { upgrading soldiers' welfare, albeit } \\
\text { within the limits of budgetary } \\
\text { allocation }\end{array}$ & $\begin{array}{l}\text { Professionalism in } \\
\text { the Armed Forces }\end{array}$ \\
\hline \multirow[t]{2}{*}{2000} & \multirow[t]{2}{*}{$\begin{array}{l}\text { Demilitarization of } \\
\text { Public Order and } \\
\text { Civilian Policing }\end{array}$} & \multirow[t]{2}{*}{$\begin{array}{l}\text { Olusegun } \\
\text { Obasanjo Regime }\end{array}$} & $\begin{array}{l}\text { (1).Creation of } 37 \text { state } \\
\text { commands, } 106 \text { area commands, } \\
925 \text { police divisions, } 2,190 \text { police } \\
\text { stations throughout the country; }\end{array}$ & \multirow[t]{2}{*}{$\begin{array}{l}\text { Improved } \\
\text { Police-Civilian ratio }\end{array}$} \\
\hline & & & $\begin{array}{l}\text { (2). Increase of the number of to } \\
120,000 \text { police officers, to } \\
\text { address the acute personnel } \\
\text { shortage }\end{array}$ & \\
\hline
\end{tabular}

Source: Authors' Compilation from information provided in Abiodun, A. (2000)

These reform efforts notwithstanding, security crisis has remained a recurrent decimal in Nigeria. The implication of this is that the reforms have not been able to address security challenges. The weaknesses of the reform have been largely due to its concentration on the core security sector at the neglect of other important sectors of national security. Thus, a fundamental approach to the reform might be to adopt an all encompassing and holistic approach. This calls for a broader definition and clarification of what security sector reform entails. 
Broadly, security sector reform is concerned with the efficient use of scarce resources to address issues and problems of insecurity through institutional reforms. Issues such as democratization of societies and political process, good governance, transparency and accountability, respect for human rights and adherence to rule of law, peaceful transformation of societies, human security and poverty reduction programmes make up the components (Commission on Human Security, 2003; Brzoska, 2003; Ball, et al, 2003). Therefore, a holistic approach to security sector reform in Nigeria will entail the development of effective legislation and the creation/strengthening of governmental institutions capable of providing security, reduce poverty and bridge socio-economic inequalities which in all cases result in aggressive behaviours among the less privileged as exemplified by the Niger Delta militancy and Boko Haram insurgency.

In addition, the Nigerian state and those involved in national and international security policymaking should study and thoroughly understand the operational methodologies and instruments of these violent groups and organizations and the threats from them through inter-institutional networking and intelligence gathering. Again, agreements must be reached between the Nigerian state and its immediate territorial neighbours and the entire West African sub-region and their governments for cooperation in various areas in order to curtail transnational crime and terrorism and reduce insecurity (Duru \& Ogbonnaya, 2010).

Finally, for the core security sector, there is the urgent need for a complete and total overhauling of Nigeria's security institutions and agencies to meet the current security challenges. This will entail adequate training, funding and equipping of the security institutions, intensifying regular and timely legislative oversight of core security sectors in order to improve service delivery in the security sector.

\section{Conclusion and Policy Recommendations}

\subsection{Conclusion}

Within the scope of this study, it is established that;

1) The activities and operations of regional based violent groups in Nigeria constitute threat to the sovereignty and territoriality of the state;

2) The rise and expansion of these ethnic violent groups poses security threats to lives and property in Nigeria;

3) The operations of violent non-state actors are having negative impacts on national economic growth in Nigeria; and

4) There is a linkage between the process of globalization and the rise and expansion of ethnic militants and violent groups in Nigeria.

\subsection{Policy Recommendations}

Scholars such as de Wijk (2002), Klarevas (2004), and Remo (2007) have argued that the nature of threat posed by international terrorism does not only render traditional national security arrangements of nation -states inadequate to respond to the threat, but also have in many respects diminished state control and augmented and empowered the terrorist groups. This challenge to the dominance of the Westphalia state in international politics has become more prevalent as the state itself has become increasingly deficient. This deficiency of the state was succinctly captured by Jayantha Dhanapala, a former United Nations Under-Secretary General for Disarmament Affairs who on April 2, 2001 wrote that;

In an age of total war, of instant communications and fast cheap travel, the nation state has appeared to many observers as a quaint, even dangerous anachronism. Modern technology has rendered the nation-state obsolete as a principle of political organization, for the nation-state is no longer able to perform what is the elementary function of any political organization: to protect the lives of its members and their way of life. The modern technologies of transportation, communications, and warfare and the resultant feasibility of all -out atomic war, have completely destroyed this protective function of the state (Dhanapala, 2001: 6).

The implication of the relative or absolute decline of the state is that;

1) The Nigerian state and those involved in national and international security policymaking should study and thoroughly understand the operational methodologies and instruments of these violent and militia groups organizations and the threats from them;

2) There is the urgent need for a complete and total overhauling of the security institutions of the Nigerian state to meet the current security challenges confronting the state. This will entail adequate training, funding and equipping of these security institutions; 
3) Global agreements must be reached among states and their governments for cooperation in various areas in order to curtail international crime and terrorism and reduce global insecurity and poverty and also bridge socio-economic inequalities which in most cases result in aggressive behaviours among the less privileged as exemplified by the Niger Delta militancy and Boko Haram insurgency.

\section{References}

Abiodun, A. (2000). Security reform in democratic Nigeria. Conflict, Security and Development Group Working Paper. Centre for Defence Studies, Kings College, University of London.

Afoaku, O. (2011). Boko Haram and Islamic fundamentalism in Nigeria. School of Public and Environmental Affairs, Indiana University, Bloomington, Indiana.

Agbambu, C. (2011). 'Lack of national security policy, Nigeria's major problem' Nigerian Tribune Newspaper. Retrieved from http://www.tribune.com.ng/index.php/news/25917-lack-of-national-security-policy-nigerias-major-problem

Ampatuam, T. P. (2003). Terrorism and nation-state institutions: Actions and inter-actions. Retrieved March 16, 2009 from http://www.pvtr.org/pdf/GlobalAnalysis/Nation-States\%20institutions.pdf

Awoyemi, O. (2012). Revenue allocation, insecurity and poverty in northern Nigeria. Retrieved July 5, 2012, from $\mathrm{http}: / /$ www.proshareng.com/news/16703

Aydinli, E. (2006). Globalization, security and non-state actors. Papers presented to the GW Centre for the Study of Globalization. Retrieved December 19, 2008, from http://gstudynet.org/what/events/gweek/spring06/globalization.php

Azazi, O. A. (2012). Northern Nigeria, the prosperity agenda and national security. A paper presented at the Northern Transformation Impact Submit sponsored by Arewa Transformation and Empowerment Initiative at the Arewa House, Kaduna, Kadu na State on May 10 - 12, 2012

Ball et al. (2003). Governance in the Security Sector. In Nicolas van de Walle, \& Nicole Ball (Eds.), Beyond Structural Adjustment (pp. 263-304). Palgrave.

Bar-Tal, D., \& Jacobson, D. (1998). Psychological Perspectives on Security. Applied Psychology, 47(1), 59-71. http://dx.doi.org/10.1111/j.1464-0597.1998.tb00013.x

Benjamin, I., Ogunmola, A., Midat, J., \& Ibrahim, S. (2012). Government Betrayal Root Cause of Violence - US Ambassador.

Retrieved

from http://www.leadership.ng/nga/articles/29025/2012/07/06/govt_betrayal_root_cause_violence_us_ambassad or.html

Betts, R. K. (1982). Surprise attack: Lessons for defense planning. Washington D. C: Brookings.

Brzoska, M. (2003). Security sector reform in development donor perspective: Origins, theory and practice. Geneva Center for the Democratic Control of the Armed Forces (DCAF), Occasional Paper 4. Geneva, November

Buzan, B. (1991, July). New patterns of global security in the twenty-first century. International Affairs Royal Institute of International Affairs, 67(3), 431-451.

Cable News Network (CNN). (2012, June). Syria - related clashes rage in Lebanon, leaving 13 Dead. Retrieved August 13, 2012, from http://edition.cnn.com/2012/06/03/world/meast/lebanon-syria-violence/

Cameron, W. B., \& McCormick, T. C. (1954). Concepts of security and insecurity. American Journal of Sociology, 59(6), 556-564. http://dx.doi.org/10.1086/221442

Centre for Environment, Human Rights and Development (CEHRD). (2006). Soldiers, police seize high caliber riffles in Rivers. Newsletters, 1.

Cesarz et al. (2003). Alienation and militancy in Nigeria's Niger Delta. Africa Notes. Washington Centre for Strategic and International Studies, No. 16, May.

Clark, I. C. (1997). Globalization and fragmentation: International relations in the twentieth century. Oxford: Oxford University Press.

Commission on Human Security, CHS. (2003). Human Security Now, United Nations Office for Project Services, UNOPS, New York. 
Crenshaw, M. (1985). Theories of terrorism: Instrumental and organizational approaches. A paper presented at the Defense Nuclear Agency's $10^{\text {th }}$ Annual symposium on the Role of the Behavioural Sciences in Physical Security, April. Retrieved from http://www.psci.edu/jbook/crenshaw.pdf

De Wijk, R. (2002). The limits of military power. In P. Howard (Ed.), Defeating terrorism. New York: McGraw - Hill

Dhanapala, J. (2001). Globalization and the nation state. Colorado Journal of International Environmental Law and Policy. $\quad$ Retrieved December 19, 2008, from http://www.globalpolicy.org/nations/future/2003/0530blob.htm

Duru, E. J. C., \& Ogbonnaya, U. M. (2010). Globalization, international terrorism and national security challenges in contemporary world order. Kogi Journal of Politics, 1(1), 1-9.

Ebienfa, K. I., \& Nwaodike, C. A. (2010). Globalization and the Niger Delta crisis. Centre for the Advancement of Socio-Political and Environmental Justice, Yenagoa, Saturday, February 20.

Ellen, B., Salemink. O., \& Eriksen, T. H. (2010). A world of insecurity: Anthropological perspectives on human security. London: Pluto.

Eso, H. (2011). Boko Haram: The Enemy Within. Retrieved March 6, 2012, from http://www.kwenu.com/moe/2011/boko_haram_enemy_within.htm

Ezeribe, E. (2009, December 28). Beyond the Nigerian terrorist bomber. Daily Sun.

Fayemi, K. J., \& 'Olonisaki, F. (2008). Nigeria. In A. Bryden, B. N'Diaye, \& F. Olonisakin (Eds.), Challenges of Security Sector Governance in West Africa. Geneva Centre for the Democratic Control of Armed Forces (DCAF) LIT

Francis, D. J. (2013). The regional impact of the armed conflict and French intervention in Mali. Norwegian Peace-Building Resource Centre (NOREF) Report, April.

Haftendorn, H. (1991). The security puzzle: Theory-building and discipline-building in international security. International Studies Quarterly, 35(1), 3-17. http://dx.doi.org/10.2307/2600386

Harrington, E. (2012). Religion is not driving extremist violence in Nigeria, says Obama official after church bombings. CNS News. Retrieved May 5, 2012, from http://www.cnsnews /news/article/

Ibrahim, S. (2012). Boko Haram destroying the north, FG cries out. Leadership, Thursday, February 9, 2012. Retrieved from www.leadership.ng/nga/articles

International Crisis Group. (2013). Mali: Security, Dialogue and Meaningful Reform. Africa Report No. 201, April 11.

Karacasulu, N. (2006). Security and globalization in the context of international terrorism. Review of International Law and Politics, Ankara, 2(5), 1-17

Klarevas, L. (2004). Political realism: A culprit for the 9/11 Attacks. Harvard International Review, 26(3). Retrieved August 16, 2007 from http://www.harvard.edu/articles/print.php?article=1252

Mickolus, E. F. (1976). Negotiating for hostages: A policy dilemma. Orbis, 19(4), 13-25.

Musa, I. G. (2012). How Insecurity Is Killing Nigeria's Largest Grains Market. Weekly Trust, Saturday, 24 March.

Negroponte, J. D. (2006). Annual threat assessment of the Director of National Intelligence presented to the United States of American Senate Committee on Intelligence, February 2.

Ogbonnaya, U. M. (2011, October). Environmental law and underdevelopment in the Niger Delta. African Research Review, 5(5), 68-82.

Okpaga, A, Ugwu Sam Chijioke, U. S., \& Eme, O. I. (2012). Activities of Boko Haram and Insecurity Question in Nigeria. Arabian Journal of Business and Management Review (OMAN Chapter), 1(9), 77-99. http://dx.doi.org/10.12816/0002163

Onuoha, F. C. (2011). Small arms and light weapons proliferation and human security in Nigeria. Conflict Trends, Issue 1:50-56, African Centre for the Constructive Resolution of Disputes (ACCORD), Pretoria.

Remo, W. (2007). Protectors and predators: Why is there a difference among West African militias? In L. Andersen, B. Moller, \& F. Stepputat (Eds.), Fragile states and insecure people: Violence, security and statehood in twenty-first century (pp. 99-122). New York: Palgrave Macmillan. 
Schelling, T. C. (1966). Arms and influence. New Haven CT: Yale University Press.

The Nigerian Voice. (2012). Security heightens in Kaduna ... FG says BH attacks make north economically backward. Retrieved February 9, 2012, from http://www.thenigerianvoice.com/nvnews

Trzeciak-Duval, A., \&Van Veen, E. (2012). Globalization with a twist: Volatility and fragility all in one. Stability: International Journal of Security and Development, 1(1), 80-88. http://dx.doi.org/10.5334/sta.ag

United States Commission on International Religious Freedom (USCIRF) Annual Report 2012 - Countries of Particular Concern: Nigeria, 20 March 2012. Retrieved July, 4, 2012, from http://www.unhcr.org/refworld/docid/4f71a675a.html

Walker, A. (2012, June). What Is Boko Haram? United States Institute of Peace Special Report 308.

Williams, P. (2008). Violent non-state actors and national and international security. International Relations and Security Network Series. Zurich: Swiss Institute of Technology. Retrieved March 16, 2009, from $\mathrm{http} / / / \mathrm{se} 2$. isn.ch/serviceengine/filecontent?serviceID.ISFPub\&field=8EEBA9FE-AA15-32FC9434Alng=en

\section{Copyrights}

Copyright for this article is retained by the author(s), with first publication rights granted to the journal.

This is an open-access article distributed under the terms and conditions of the Creative Commons Attribution license (http://creativecommons.org/licenses/by/3.0/). 